\title{
PharmacoMicrobiomics or how bugs modulate drugs: an educational initiative to explore the effects of human microbiome on drugs
}

\author{
Ramy K Aziz ${ }^{1,2^{*}}$, Rama Saad ${ }^{3}$, Mariam R Rizkallah ${ }^{4}$ \\ From 10 ${ }^{\text {th }}$ Annual UT-ORNL-KBRIN Bioinformatics Summit 2011 \\ Memphis, TN, USA. 1-3 April 2011
}

\section{Background}

Pharmacogenomics investigates how variations within the human genome affect the action and disposition of drugs as well as drug tolerance [1]. Yet, variations within the human genome do not fully account for the tremendous phenotypic variations observed between individuals. Human-associated microbes, which exceed the human cells in number, significantly contribute to the effective human gene pool, and their combined genomes (known as the human microbiome) have not gained attention until recently. The Human Microbiome Project was launched in 2007 to catalogue the tremendous diversity of cultured and uncultured human-associated microbial communities residing in different human tissues, and to study the effect of microbial genes and genomes on human health and disease $[2,3]$. However, the effect of these microbes on drugs remains largely unexplored. Since microbes have complex metabolism, including an extraordinary ability to metabolize xenobiotics [4-6], they are expected to play a pivotal role in modulating the action, disposition, and toxicity of drugs with which they interact in different sub-ecosystems within the human body [7].

\section{Materials and methods}

The PharmacoMicrobiomics initiative (http://pharmacomicrobiomics.org) is a research-based educational

Table 1 Examples of effects of gut microbes on drugs

\begin{tabular}{|c|c|c|c|c|}
\hline CID & Drug & $\begin{array}{l}\text { Body } \\
\text { Site }\end{array}$ & Microbial effects & $\begin{array}{l}\text { NCBI } \\
\text { PMID }\end{array}$ \\
\hline 64982 & $\begin{array}{l}\text { Baicalin [Potential antioxidant, anti- } \\
\text { inflammatory and liver tonic] }\end{array}$ & Gut & $\begin{array}{l}\text { Gut microbes hydrolyze baicalin and enhance its absorption. Absence of gut } \\
\text { microbiota resulted in lower levels of baicalin in plasma following oral } \\
\text { administration [8]. }\end{array}$ & 11197087 \\
\hline 2724385 & Digoxin [Cardiac glycoside] & Gut & $\begin{array}{l}\text { Eubacterium lentum is responsible for the difference in metabolite concentration } \\
\text { of digoxin between North Americans and Southern Indians [9] }\end{array}$ & 2759492 \\
\hline 1794427 & Chlorogenic acid [Antioxidant] & Gut & Variation in gut microbiome alters chlorogenic acid metabolism [10]. & 12771329 \\
\hline 1983 & $\begin{array}{l}\text { Acetaminophen [Analgesic and } \\
\text { antipyretic] }\end{array}$ & Gut & $\begin{array}{l}\text { Acetaminophen toxicity is associated with elevated levels of p-cresol produced by } \\
\text { some bacterial communities [4]. }\end{array}$ & 19667173 \\
\hline 9064 & $\begin{array}{l}\text { (+)- catechin and (-)-epichatechins } \\
\text { [Anti-oxidants] }\end{array}$ & Gut & $\begin{array}{l}\text { In germ-free rats, }(+) \text {-catechins and (-)-epicatechins resulted in increase in the } \\
\text { levels of liver CYP450 2C11, and }(+) \text { catechins caused elevation in the specific } \\
\text { activity of liver UGT-Chloramphenicol [11]. }\end{array}$ & 12659723 \\
\hline 5734 & Zonisamide [Anticonvulsant] & Gut & $\begin{array}{l}\text { Gut microbiota reduce zonisamide into 2-sulfomoyacetylphenol. Levels of } 2 \text { - } \\
\text { sulfomoyacetylphenol reportedly increased upon re-inoculation of germ-free rats } \\
\text { with gut microbiota [12] }\end{array}$ & 9231340 \\
\hline
\end{tabular}

\footnotetext{
* Correspondence: ramy.aziz@egybio.net

'Department of Microbiology and Immunology, Faculty of Pharmacy, Cairo

University, 11562 Cairo, Egypt

Full list of author information is available at the end of the article
}

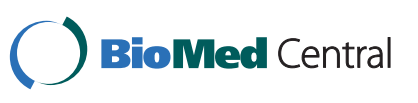

(c) 2011 Aziz et al; licensee BioMed Central Ltd. This is an open access article distributed under the terms of the Creative Commons Attribution License (http://creativecommons.org/licenses/by/2.0), which permits unrestricted use, distribution, and reproduction in any medium, provided the original work is properly cited. 
web platform that aims at exploring how microbes modulate drugs. The project was launched as an educational platform to introduce bioinformatics and microbial genomics to pharmacy students while benefiting the research community. The first step of this project was mining existing literature and extracting known microbe-drug interactions using a combination of keywords in an iterative process. The second step was the manual curation of the extracted literature data and their classification by drug classes, microbial families, and body systems (e.g., Table 1). The third step is the creation of a relational database that includes the microbes at different body sites and their effects on drugs' pharmacokinetic and pharmacodynamic properties. Finally, participating students screen and attempt to isolate fecal microbes that alter a specific drug, and each student selects a drug class and a microbial species within a body site to examine their complex interaction in vitro.

\section{Conclusion}

The literature-mining steps of the pharmacomicrobiomics project have resulted in the initiation of a continuously updated web portal maintained by students (http://pharmacomicrobiomics.org/papers and http:// pharmacomicrobiomics.com/examples.html). The project is expected to build a knowledge base that allows interested students and scholars, in the future, to predict the behavior of untested members of drug classes or

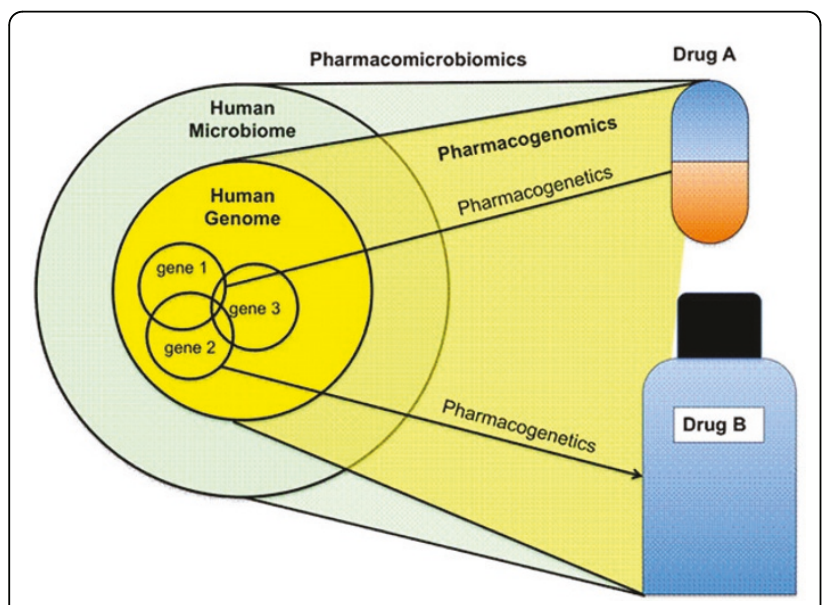

Figure 1 Pharmacogenetics investigates the effect of variations within single genes on drugs; pharmacogenomics investigates the effect of the sum of variations within the human genome on drugs; pharmacomicrobiomics investigates the effect of variations within the human microbiome on drugs. unstudied microbial species, and to design laboratory experiments for testing these predictions.

\section{Author details}

'Department of Microbiology and Immunology, Faculty of Pharmacy, Cairo University, 11562 Cairo, Egypt. ${ }^{2}$ Department of Computer Science, San Diego State University, San Diego, CA, 92182, USA. ${ }^{3}$ Department of Biology, School of Sciences and Engineering, The American University in Cairo, 11835 Cairo, Egypt. ${ }^{4}$ Open Source Technologies Department, Information Technology Institute, 12577 Giza, Egypt.

Published: 5 August 2011

\section{References}

1. Nebert DW, Zhang G, Vesell ES: From human genetics and genomics to pharmacogenetics and pharmacogenomics: past lessons, future directions. Drug Metab Rev 2008, 40:187-224.

2. Turnbaugh PJ, Ley RE, Hamady M, Fraser-Liggett CM, Knight R, Gordon Il: The human microbiome project. Nature 2007, 449:804-810.

3. Peterson J, Garges S, Giovanni M, Mclnnes P, Wang L, Schloss JA, Bonazzi V, McEwen JE, Wetterstrand KA, Deal C, et al: The NIH Human Microbiome Project. Genome Res 2009, 19:2317-2323.

4. Clayton TA, Baker D, Lindon JC, Everett JR, Nicholson JK: Pharmacometabonomic identification of a significant host-microbiome metabolic interaction affecting human drug metabolism. Proc Natl Acad Sci USA 2009, 106:14728-14733.

5. Wilson ID, Nicholson JK: The role of gut microbiota in drug response. Curr Pharm Des 2009, 15:1519-1523.

6. Wilson ID: Drugs, bugs, and personalized medicine: pharmacometabonomics enters the ring. Proc Natl Acad Sci USA 2009, 106:14187-14188.

7. Rizkallah M, Saad R, Aziz R: The Human Microbiome Project, personalized medicine and the birth of pharmacomicrobiomics. Cur Pharmacog Personalized Med (Formerly Current Pharmacog) 2010, 8:182-193.

8. Akao T, Kawabata K, Yanagisawa E, Ishihara K, Mizuhara Y, Wakui Y, Sakashita Y, Kobashi K: Baicalin, the predominant flavone glucuronide of scutellariae radix, is absorbed from the rat gastrointestinal tract as the aglycone and restored to its original form. J Pharm Pharmacol 2000, 52:1563-1568.

9. Mathan VI, Wiederman J, Dobkin JF, Lindenbaum J: Geographic differences in digoxin inactivation, a metabolic activity of the human anaerobic gut flora. Gut 1989, 30:971-977.

10. Gonthier MP, Verny MA, Besson C, Remesy C, Scalbert A: Chlorogenic acid bioavailability largely depends on its metabolism by the gut microflora in rats. J Nutr 2003, 133:1853-1859.

11. Lhoste EF, Ouriet V, Bruel S, Flinois JP, Brezillon C, Magdalou J, Cheze C, Nugon-Baudon L: The human colonic microflora influences the alterations of xenobiotic-metabolizing enzymes by catechins in male F344 rats. Food Chem Toxicol 2003, 41:695-702.

12. Kitamura S, Sugihara K, Kuwasako M, Tatsumi K: The role of mammalian intestinal bacteria in the reductive metabolism of zonisamide. J Pharm Pharmacol 1997, 49:253-256.

doi:10.1186/1471-2105-12-S7-A10

Cite this article as: Aziz et al:: PharmacoMicrobiomics or how bugs modulate drugs: an educational initiative to explore the effects of human microbiome on drugs. BMC Bioinformatics 2011 12(Suppl 7):A10. 